\title{
EFFECT OF IRRIGATION AND PLANT POPULATION DENSITY ON PRODUCTIVITY AND WATER USE EFFICIENCY OF SOME GENOTYPES OF SAFFLOWER (Carthamus tinctorius, L.) UNDER SOUTHERN EGYPT CONDITIONS.

\author{
Abd El-Lattief, E.A. ${ }^{1}$; F.Sh. Seedek ${ }^{2}$ and H.K.A. Rehab ${ }^{2}$ \\ ${ }^{1}$ Agron. Dept., Fac. Agric., South Valley Univ., Qena, Egypt \\ ${ }^{2}$ Oil crop Dept., Field crop Res. Inst., A.R.C., Giza, Egypt
}

\section{ABSTRACT}

This study was conducted on the Experimental Farm of the Shandaweel Research Station at Sohage, Egypt, during 2006/07 and 2007/08 growing seasons. The investigation was aimed to study the effect of irrigation at 45,60 and $75 \%$ of available soil water deficit (ASMD) and two plant population densities (35000 and 70000 plants/ fad.) on productivity and water use efficiency of some genotypes (Lines 1, 2, 3 and Giza1 cv) of safflower. A randomized complete block, split- split plot design with three replicates was used in each season. Irrigation treatments, genotypes and plant population densities were randomly assigned to the main, sub-plots and subsub plots, respectively.

Results showed that irrigation at $45 \%$ of ASMD significantly increased plant height, number of branches /plant, number of heads /plant, 100-seed weight, weight of seeds /plant, seed yield /fad., seed oil content and oil yield /fad. by 35.0, 45.8, 50.6 $13.9,49.9,34.0,7.3$ and $43.8 \%$, respectively, compared to irrigation at $75 \%$ of ASMD.

Increasing plant population densities from 35000 to 70000 plants /fad. significantly increased plant height, seed and oil yield fad ${ }^{-1}$, while, decreased number of branches /plant, number of heads /plant, 100-seed weight, weight of seeds /plant. In this case, seed oil content was not affected by plant population density. In general, Line 3 surpassed others genotypes in the most studied characteristics.

The interaction between irrigation regime $x$ genotype as well as irrigation regime $x$ plant population density had a significant effect on the 100 -seed weight, seed weight/plant, seed yield /fad., seed oil content, oil yield /fad and WUE. Meanwhile, interaction between plant population density $x$ genotype or between three factors, had a significant effect on seed yield /fad. and WUE only.

Seasonal water consumptive use was 30.03, 26.05 and $23.95 \mathrm{~cm}$ when irrigated safflower plants at $45 \%, 60 \%$ and $75 \%$ of ASMD, respectively. Results indicated that irrigation at $60 \%$ of ASMD gave the highest value of WUE $(31.32 \mathrm{~kg}$ seed yield $\mathrm{cm}^{-1}$ of water consumed). Also, plant population densities at 70000 plants /fad. gave the highest value of WUE. Moreover, Line 3 was more efficient in water use than other genotypes.

So, from results of seed yield and WUE, a high or medium irrigation rates with high plant population densities and planted safflower genotype Line 3 are adequate under this study condition.

Keywords: Safflower, ASMD, population density, oil content, oil yield, WUE.

\section{INTRODUCTION}

Safflower (Carthamus tinctorius, L.) is considered as one of the most important oilseed crops in the world due to its numerous uses of both flower petals and edible oil. The seeds contain $30-40 \%$ oil, $15-20 \%$ protein and $35-$ $45 \%$ hull fraction (Rahamatalla et al., 2001). It has attracted significant 
Abd El-Lattief, E.A. et al.

interest as an alternative oil seed due to its high adaptability for dry climatic conditions with little precipitation. This plant is considered as a drought tolerant crop which is capable of obtaining moisture from levels not available to the majority of crops (Weiss, 2000). Safflower can also be grown successfully on soil with poor fertility and in areas with relatively low temperatures (Koutroubas and Papakosta, 2005).

Water element is a major constant of tissue and is essential for cell enlargement and growth. Soil moisture in the root zone plays an important role in plant growth and its yield. In this case, Mekki et al (1993) revealed that plant height, seed yield /plant, number of heads /plant and seed oil content were reduced as water depletion level increased. Also, who found that highest values of seed yield /plant, number of heads /plant and 100-seed weight were recorded with Demo $157 \mathrm{cv}$ and irrigated at 35\% of ASMD. Eid (1991) indicated that weight of seeds /plant and seed yield /fad. of safflower varieties increased when plants were irrigated with $50 \%$ from filed capacity. Katara and Bansal (1995) found that increasing irrigation number increased seed yield /ha. Also, they added that seasonal water consumptive use increased with an increase in number of irrigations from 1 to 3 (145.5 to 236.0 $\mathrm{mm}$ ), whereas water use efficiencies declined considerably from 14.2 to 11.0 $\mathrm{kg}$ seeds $/ \mathrm{ha} / \mathrm{mm}$. Ibrahim et al (2008) who mentioned that water consumptive use by safflower plants increased as the available soil moisture around the root zone increased. Also, who added that the best water use efficiency (WUE) for seed production was obtained from irrigated safflower plants at $60 \%$ of ASMD.

Concerning genotypes, El-Gayar et al (1990), Mundel and Braun (1999), Mundel et al (1999) and Camas et al (2007) stated that safflower genotypes varied significantly in seed yield and its attributes, oil percent and oil yield per unit area.

Regarding the plant density effect, Abo-Shetaia (1990) found that lower density (70000 plants /fad.) gave significantly the highest number of branches /plant, number of heads /plant and seed index than higher density (105000 plants /fad.), while the reverse was true for seed yield /fad. El-Hariri and Ahmed (1993) stated that the 70000 plants stand/ fad. exceeded both 35000 and 105000 plants /fad. respecting plant height, seed yield /plant or fad ${ }^{-1}$. Gonzalez et al (1994) showed that plant population did not influence seed oil content. Ghanem and Ash-Shormillesy (2007) mentioned that plant densities at 35000 plants/ fad. gave the highest seed yield /plant compared with others plant densities at 46666, 70000 and 93333 plants /fad. Pourhadian and Khajehpour (2008) found that highest (3039 kg /ha) and lowest (1930 kg /ha) seed yields were obtained with 20 and $40 \mathrm{~cm}$ row distances, respectively.

\section{MATERIALS AND METHODS}

This study was conducted on the Experimental Farm of the Shandaweel Research Station at Sohage, Governorate $\left(26^{\circ} 34^{\prime} \mathrm{N}, 31^{\circ} 42^{\prime} \mathrm{E}\right.$, and $61 \mathrm{~m}$ above mean sea level) during the 2006/2007 and 2007/2008 growing seasons. The experimental soil was clay loam in texture with $\mathrm{pH}$ value of 7.72 , organic 
matter content of $1.53 \%$, total $\mathrm{N} 1.15 \%$, available $\mathrm{P}$ and $\mathrm{K}$ of $17.22,148 \mathrm{ppm}$, respectively (averages of the two seasons for the upper $25 \mathrm{~cm}$ of the soil). Soil water contents of the experimental soil are given in Table 1. Soil bulk density was determined with a classical method, using cylinders $100 \mathrm{~mm}$ wide and $60 \mathrm{~mm}$ in height according to Grossmann and Reinsch (2002). Soil field capacity and wilting point were determined in the laboratory using the method described by Cassel and Nielsen (1986).

Table 1: Soil moisture constants for the experimental site.

\begin{tabular}{|c|c|c|c|c|}
\hline $\begin{array}{c}\text { Soil depth } \\
\text { (cm) }\end{array}$ & $\begin{array}{c}\text { Field } \\
\text { capacity (\%) }\end{array}$ & $\begin{array}{c}\text { Wilting } \\
\text { point (\%) }\end{array}$ & $\begin{array}{c}\text { Bulk } \\
\text { density (\%) }\end{array}$ & $\begin{array}{c}\text { Available } \\
\text { soil water (\%) }\end{array}$ \\
\hline $0-15$ & 25.50 & 11.55 & 1.28 & 13.95 \\
$15-30$ & 28.48 & 13.12 & 1.33 & 15.36 \\
$30-45$ & 29.03 & 13.25 & 1.34 & 15.78 \\
$45-60$ & 33.12 & 15.75 & 1.36 & 17.37 \\
\hline
\end{tabular}

Nitrogen fertilizer was applied at a rate of $60 \mathrm{~kg} / \mathrm{fad}$. in the form of urea $(46.5 \% \mathrm{~N})$ as fertigation. Nitrogen fertilizer was added in two equal doses, at 21 and 42 days after sowing. Phosphorus fertilizer was applied at a level of $150 \mathrm{~kg} / \mathrm{fad}$. as calcium super phosphate $\left(15.5 \% \mathrm{P}_{2} \mathrm{O}_{5}\right)$. Whole of phosphorus was applied basally before sowing in all treatments. Potassium fertilizer was applied at a level of $50 \mathrm{~kg} \mathrm{fad}^{-1}$ as potassium sulphate $(48 \%$ $\mathrm{K}_{2} \mathrm{O}$ ) in two equal doses every 3 weeks after sowing. Weed, pests, and diseases control were done in a timely manner.

A randomized complete block split split- plot design with three replicates was used in each season. Irrigation treatments, genotypes (Lines 1, 2, 3 and Giza1 cv) and plant population densities (35000 and 70000 plants /fad.) were randomly assigned to the main, sub-plots and sub-sub plots, respectively. Irrigation treatments started after the first irrigation and were timed, through soil moisture samples, at 45,60 and $75 \%$ of available soil water deficit. Sub-sub plot area was $24 \mathrm{~m}^{2}$ including 8 ridges, $5 \mathrm{~m}$ long and $60 \mathrm{~cm}$ apart. Plots were isolated by ditches of $1.5 \mathrm{~m}$ in width to avoid lateral movement of water. Genotypes seeds were sown by hand on November $8^{\text {th }}$ and $10^{\text {th }}$ in the first and second seasons, respectively. Planting was in hills 20 $\mathrm{cm}$ apart, and seeding rate was $12 \mathrm{~kg} / \mathrm{fad}$. The preceding crop was grain sorghum in both seasons. The origin of genotypes was shown in Table 2.

Table 2: The origin of safflower genotypes.

\begin{tabular}{|c|c|c|}
\hline Genotypes & Number & Origin \\
\hline Line 1 & 1697 & Cyprus \\
Line 2 & 1699 & Ethiopia \\
Line 3 & 152 & India \\
Giza 1 & -- & Egypt \\
\hline
\end{tabular}

Hand harvesting was performed about 160 days after sowing. Ten guarded plants were randomly taken from each sub-sub plot to measure plant height $(\mathrm{cm})$, number of branches and heads / plant, 100-seed weight $(\mathrm{g})$ and weight of seeds /plant. Seed yield ( $\mathrm{kg} / \mathrm{fad}$.) was determined from the six central ridges. Seed oil percentage was calculated by using the modified 
Soxhlet Apparatus and pure petroleum ether as a solvent, according to A.O.A.C. (1984). Oil yield ( $\mathrm{kg} / \mathrm{fad}$.) was calculated by multiplying seed yield ( $\mathrm{kg} / \mathrm{fad}$.) by seed oil content (\%).

Water consumptive use $(\mathrm{cm})$ was calculated using the following equation (Hansen et al, 1979): $\mathrm{CU}=\sum \mathrm{D}_{\mathrm{i}}{ }^{*} \mathrm{Dbi}_{\mathrm{b}}{ }^{*}\left(\mathrm{PW} \mathrm{W}_{2}-\mathrm{PW} \mathrm{W}_{1}\right) / 100$.

Where: $\mathrm{CU}=$ water consumptive use $(\mathrm{cm})$ in the effective root zone $(60 \mathrm{~cm})$.

$D_{i}=$ soil layer depth $(15 \mathrm{~cm})$.

$D_{b i}=$ soil bulk density, $\left(\mathrm{g} \mathrm{cm}^{-3}\right)$ for this depth.

$\mathrm{PW}_{1}=$ gravimetric soil moisture percentage before irrigation .

$\mathrm{PW}_{2}=$ gravimetric soil moisture percentage, 48 hours after irrigation Meanwhile, water use efficiency was calculated according to Jensen (1983). WUE $=\mathrm{Y} / \mathrm{CU}$.

Where: $\mathrm{WUE}=$ water use efficiency $\left(\mathrm{kg}\right.$ seed yield $\mathrm{cm}^{-1}$ of water consumed)

$\mathrm{Y}=$ seed yield $\left(\mathrm{kg} \mathrm{fad}^{-1}\right)$.

$\mathrm{CU}=$ seasonal water consumptive use $(\mathrm{cm})$.

Data of each season were subjected to analysis of variance and the test of homogeneity of variance was done (Bartlett's test of homogeneity) and the combined analysis of both seasons was performed, as described by Gomez and Gomez (1984). The significant differences among the treatment means were judged with the help of Duncan's multiple range test (Duncan, 1955). In the interaction, Figures were used for the comparison among various interactions.

\section{RESULTS AND DISCUSSION}

The means between years were similar according to the Bartlett homogeneity test. Therefore, data presented correspond to the means of the two years.

\section{Yield, yield attributes and seed oil content:}

The irrigation treatments exhibited significant changes in all the studied characteristics recorded in Table 3. Irrigation at $45 \%$ of ASMD significantly increased plant height, number of branches /plant, number of heads /plant, 100- seed weight, weight of seeds /plant, seed yield /fad., seed oil content and oil yield /fad. by 35.0, 45.8, 50.6, 13.9, 49.9, 34.0, 7.3 and $43.8 \%$, respectively, compared to irrigation at $75 \%$ of ASMD. A higher seed yield of safflower at $45 \%$ of ASMD could be attributed to the higher yield components such number of branches/ plant, number of heads /plant, 100seed weight, weight of seeds/ plant (Table 3). These results were in agreement with those obtained by Eid (1991), Mekki et al (1993) and Katara and Bansal (1995) who concluded that yield and its attributes of safflower were gradually increased as a result of increasing the availability of soil moisture content.

Data exhibited in Table 3, revealed that plant height, number of branches / plant, number of heads /plant, 100-seed weight, weight of seeds /plant, seed yield/fad. seed oil content and oil yield /fad. were significantly affected by safflower genotypes. Line 3 surpassed others genotypes in the most studied characteristics. Meanwhile, Line 1 and Giza 1 surpassed others genotypes in the 100-seed weight and seed oil content, respectively. In 
general, the superiority of Line 3 on others genotypes in theses characteristics may be attributed inherently to the greater ability of such Line in synthesizing more assimilates that partitioned to the final economical yields of safflower plants and the consequent dry matter accumulation. Similar safflower genotype differences were expressed by El-Gayar et al (1990), Mundel and Braum (1999), Mundel et al (1999) and Camas et al (2007).

Table 3: Mean values of yield, yield attributes, seed oil content and water use efficiency (WUE) of some safflower genotypes as affected by irrigation and plant population density in the combined analysis over both seasons.

\begin{tabular}{|c|c|c|c|c|c|c|c|c|c|}
\hline Treatments & $\begin{array}{c}\text { Plant } \\
\text { height } \\
(\mathrm{cm})\end{array}$ & $\begin{array}{c}\text { No. of } \\
\text { branche } \\
\text { s /plant }\end{array}$ & $\begin{array}{l}\text { No. of } \\
\text { heads } \\
\text { /plant }\end{array}$ & $\begin{array}{c}100- \\
\text { seed } \\
\text { weight } \\
(\mathrm{g})\end{array}$ & $\begin{array}{c}\text { Seed } \\
\text { weight } \\
\text { /plant(g) }\end{array}$ & $\begin{array}{l}\text { Seed } \\
\text { yield } \\
\operatorname{fad}(\mathrm{kg})\end{array}$ & $\begin{array}{c}\text { Seed oil } \\
\text { content } \\
(\%)\end{array}$ & \begin{tabular}{|c|} 
Oil \\
yield \\
/fad( \\
kg)
\end{tabular} & $\begin{array}{l}\text { WUE } \\
(\mathrm{kg} / \mathrm{cm})\end{array}$ \\
\hline $\begin{array}{l}\text { Irrigation (I): } \\
45 \% \text { of SAMD } \\
45 \% \text { of SAMD } \\
45 \% \text { of SAMD }\end{array}$ & & $\begin{array}{l}8.621 \mathrm{a} \\
7.517 \mathrm{~b} \\
5.913 \mathrm{c}\end{array}$ & $\begin{array}{l}33.12 \mathrm{a} \\
27.75 \mathrm{~b} \\
21.99 \mathrm{c}\end{array}$ & $\begin{array}{l}4.583 \mathrm{a} \\
4.544 \mathrm{~b} \\
4.025 \mathrm{c}\end{array}$ & $\begin{array}{l}39.03 \mathrm{a} \\
32.84 \mathrm{~b} \\
26.04 \mathrm{c}\end{array}$ & $\begin{array}{l}902 a \\
816 b \\
673 c\end{array}$ & & $\begin{array}{l}299 a \\
266 b \\
208 c\end{array}$ & $\begin{array}{l}30.05 \mathrm{~b} \\
31.32 \mathrm{a} \\
28.09 \mathrm{c}\end{array}$ \\
\hline $\begin{array}{l}\text { Genotypes(G): } \\
\text { Line 1 } \\
\text { Line 2 } \\
\text { Line 2 } \\
\text { Giza 1 }\end{array}$ & \begin{tabular}{|l|}
$161.6 \mathrm{c}$ \\
$167.3 \mathrm{~b}$ \\
$177.7 \mathrm{a}$ \\
$160.8 \mathrm{c}$ \\
\end{tabular} & $\begin{array}{l}6.789 \mathrm{c} \\
7.417 \mathrm{~b} \\
8.014 \mathrm{a} \\
7.181 \mathrm{bc}\end{array}$ & $\begin{array}{l}26.10 \mathrm{~b} \\
28.33 \mathrm{a} \\
29.61 \mathrm{a} \\
26.54 \mathrm{~b} \\
\end{array}$ & $\begin{array}{l}4.244 \mathrm{a} \\
4.369 \mathrm{~b} \\
4.628 \mathrm{~b} \\
4.294 \mathrm{~b}\end{array}$ & $\begin{array}{l}30.59 \mathrm{c} \\
35.04 \mathrm{~b} \\
37.06 \mathrm{a} \\
27.87 \mathrm{~d}\end{array}$ & $\begin{array}{l}768 \mathrm{c} \\
802 \mathrm{~b} \\
886 \mathrm{a} \\
732 \mathrm{~d}\end{array}$ & $\begin{array}{c}31.03 \mathrm{c} \\
31.50 \mathrm{bc} \\
32.41 \mathrm{~b} \\
34.14 \mathrm{a}\end{array}$ & $\begin{array}{l}239 c \\
254 b \\
288 a \\
251 b c\end{array}$ & $\begin{array}{l}28.81 \mathrm{c} \\
29.97 \mathrm{~b} \\
33.04 \mathrm{a} \\
27.45 \mathrm{~d}\end{array}$ \\
\hline \begin{tabular}{|l|} 
Plant density(D): \\
One plant /hill \\
Two plants /hill \\
\end{tabular} & $\begin{array}{l}163.1 \mathrm{~b} \\
170.6 \mathrm{a}\end{array}$ & $\begin{array}{l}7.779 \mathrm{a} \\
6.921 \mathrm{~b} \\
\end{array}$ & $\begin{array}{l}29.29 a \\
25.94 b \\
\end{array}$ & $\begin{array}{l}4.624 \mathrm{a} \\
4.144 \mathrm{~b} \\
\end{array}$ & $\begin{array}{l}35.24 \mathrm{a} \\
30.04 \mathrm{~b} \\
\end{array}$ & $\begin{array}{l}714 \mathrm{~b} \\
880 \mathrm{a}\end{array}$ & & $\begin{array}{l}230 \mathrm{~b} \\
286 \mathrm{a} \\
\end{array}$ & $\begin{array}{l}26.66 \mathrm{~b} \\
32.98 \mathrm{a} \\
\end{array}$ \\
\hline \begin{tabular}{|l|} 
Interactions: \\
$I \times$ season \\
$G \times$ season \\
$G \times I$ \\
$D \times$ season \\
$D \times I$ \\
$D \times G$ \\
$D \times I \times G$
\end{tabular} & $\begin{array}{l}\text { N.S } \\
\text { N.S } \\
\text { N.S } \\
\text { N.S } \\
\text { N.S } \\
\text { N.S } \\
\text { N.S }\end{array}$ & $\begin{array}{l}\text { N.S } \\
\text { N.S } \\
\text { N.S } \\
\text { N.S } \\
\text { N.S } \\
\text { N.S } \\
\text { N.S }\end{array}$ & $\begin{array}{l}\text { N.S } \\
\text { N.S } \\
\text { N.S } \\
\text { N.S } \\
\text { N.S } \\
\text { N.S } \\
\text { N.S }\end{array}$ & $\begin{array}{l}\text { N.S } \\
\text { N.S } \\
* * \\
\text { N.S } \\
* * \\
\text { N.S } \\
\text { N.S }\end{array}$ & $\begin{array}{l}\text { N.S } \\
\text { N.S } \\
\text { N. } \\
\text { N.S } \\
\text { N.S } \\
\text { N.S } \\
\text { N.S }\end{array}$ & $\begin{array}{l}\text { N.S } \\
\text { N.S } \\
* * \\
\text { N.S } \\
* * \\
* * \\
* *\end{array}$ & $\begin{array}{l}\text { N.S } \\
\text { N.S } \\
* * \\
\text { N.S } \\
* * \\
\text { N.S } \\
\text { N.S }\end{array}$ & $\begin{array}{l}\text { N.S } \\
\text { N.S } \\
* * \\
\text { N.S } \\
* * \\
\text { N.S } \\
\text { N.S }\end{array}$ & $\begin{array}{l}\text { N.S } \\
\text { N.S } \\
* * \\
\text { N.S } \\
* * \\
* * \\
* *\end{array}$ \\
\hline
\end{tabular}

Means designed by the same letter at each cell are not significant at the $5 \%$ level - N.S and ${ }^{* *}$ Denotes not significant and significant at $1 \%$, respectively.

Data in Table 3, illustrated that plant height was increased significantly by increasing plant density from 35000 (one plant /hill) to 70000 plants /fad. (two plants /hill). This may be due to the more competition between plants within the denser plant population for light. This led to reduction in light intensity in safflower canopy and encouragement of IAA synthesis. The increase in IAA concentration in stem tissues caused cell enlargement and hence plant height. In reverse, number of branches /plant, number of heads/plant, 100-seed weight, weight of seeds/plant were increased significantly by decreasing plant density. Also, in this case, plant densities at 70000 plants /fad. significantly increased seed yield /fad. and oil yield /fad. by 23.2 and $24.3 \%$, respectively, compared to plant densities at 35000 plants /fad. Meanwhile, seed oil content was not affected by plant population density. This increase in seed yield /fad. with this treatment may be attributed to the highest number of plants/ fad. under planting at two plants/ hill. These results are in harmony with those obtained by Abo-Shetaia 
Abd El-Lattief, E.A. et al.

(1990), Gonzalez et al (1994) and Ghanem and Ash-Shormillesy (2007).The interaction effect of irrigation $\mathrm{x}$ season, Genotypes $\mathrm{x}$ season or plant density $\mathrm{x}$ season was not significant for all traits (Table 3 ).

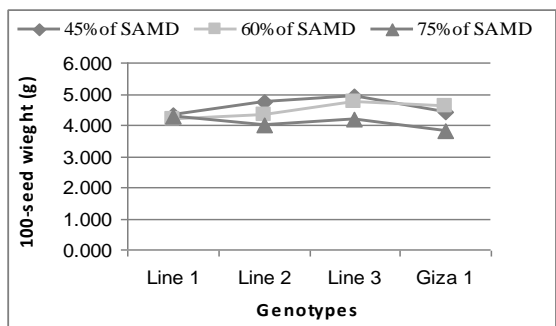

$\multimap-45 \%$ of SAMD $--60 \%$ of SAMD $\multimap 75 \%$ of SAMD

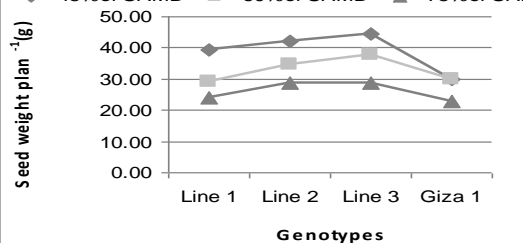

Genotypes
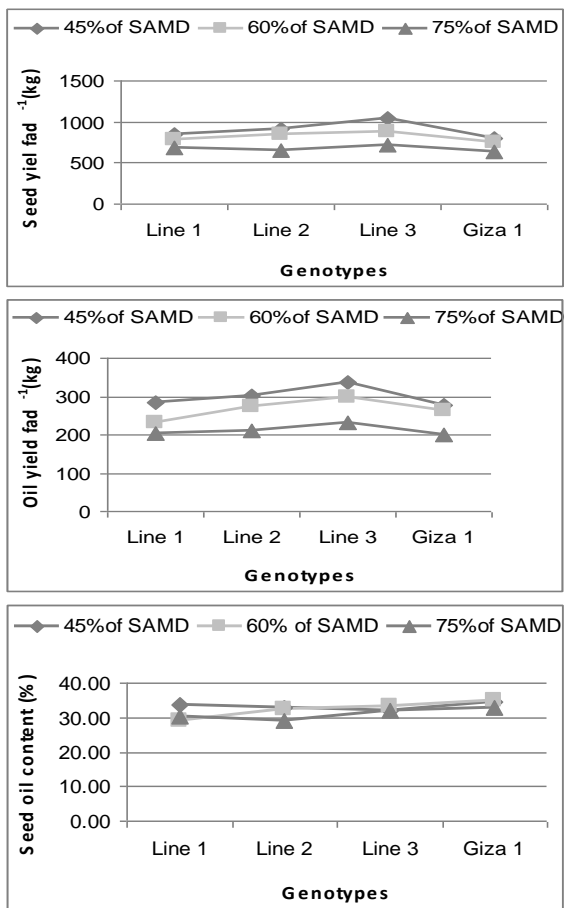

Figure 1. Effect of interaction between irrigation treatments and safflower genotypes on 100-seed weight, seed weight /plant, seed yield /fad, oil yield /fad, and seed oil content.

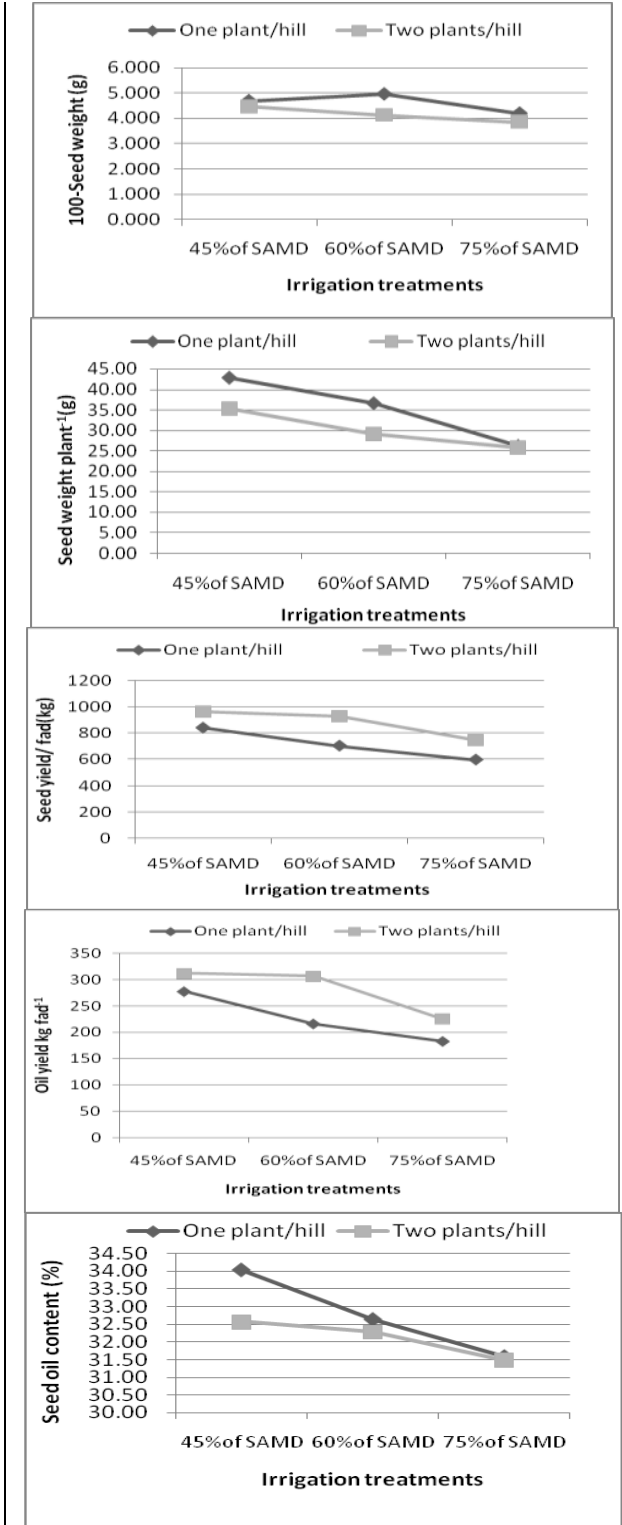

Figure 2. Effect of interaction between irrigation treatments and plant population density on 100 -seed weight, seed weight/plant, seed yield /fad, oil yield /fad, and seed oil content. 
Such results indicated that irrigation regime, safflower genotype or plant population density showed similar effects from one season to another. The interaction between irrigation regime $x$ genotype as well as irrigation regime $x$ plant population density had a significant effect on the 100-seed weight, seed weight /plant, seed yield /fad., seed oil content and oil yield/fad., as presented in Table 3, Figures 1 and 2. Figures 1 indicated that the highest values of 100-seed weight, seed weight /plant, seed yield /fad. and oil yield /fad. (4.942 g, $44.67 \mathrm{~g}, 1046 \mathrm{~kg}$ and $336 \mathrm{~kg}$, respectively) were obtained when planted safflower Line 3 and irrigated at $45 \%$ of ASMD, while, the lowest values resulted from irrigation at $75 \%$ ASMD with Giza $1 \mathrm{cv}$, that were $3.825 \mathrm{~g}, 23.02 \mathrm{~g}, 640 \mathrm{~kg}$ and $200 \mathrm{~kg}$, respectively. In this case, the heights oil percentage $(35.08 \%)$ and the lowest $(28.97 \%)$ was obtained from Giza 1 and Line 1 at irrigation with $60 \%$ of ASMD, respectively. On the other hand, Results in Figure 2 indicated that the highest values of 100 -seed weight $(4.971 \mathrm{~g})$, seed weight /plant $(42.82 \mathrm{~g})$, seed yield /fad. $(964 \mathrm{~kg})$, seed oil content (34.29\%) and oil yield /fad. (312 kg) were associated with irrigation at $60 \%$ of ASMD $\times 35000$ plants /fad., $45 \%$ of ASMD $\times 35000$ plants /fad., $45 \%$ of ASMD $\times 70000$ plants $/ \mathrm{fad}$., $60 \%$ of ASMD $\times 70000$ plants $/ \mathrm{fad}$. and $45 \%$ of ASMD $\times 70000$ plants /fad., respectively. Also, data in Figure 3 showed different response of safflower genotypes to increasing plant population density concerning seed yield /fad. Increasing plant population density from 35000 to 70000 plants /fad. increased seed yield by 26.4, 30.1, 15.6 and $22.0 \%$ for Lines 1, 2, 3 and Giza1cv, respectively. Data in Table 3 indicated that the second order interaction between three factors was significant for seed yield /fad. The data presented in Figure 4 indicated that Line 3 produced the highest seed yield /fad. $(1088 \mathrm{~kg}$ ), when planting at 70000 plants /fad. (two plants /hill) and irrigated at $45 \%$ of ASMD. The response of safflower genotype to irrigation treatments reported by Mekki et al (1993) who found that highest values of seed yield /plant, number of heads /plant and 100-seed weight were recorded with Demo $157 \mathrm{cv}$ and irrigated at $35 \%$ of ASMD.

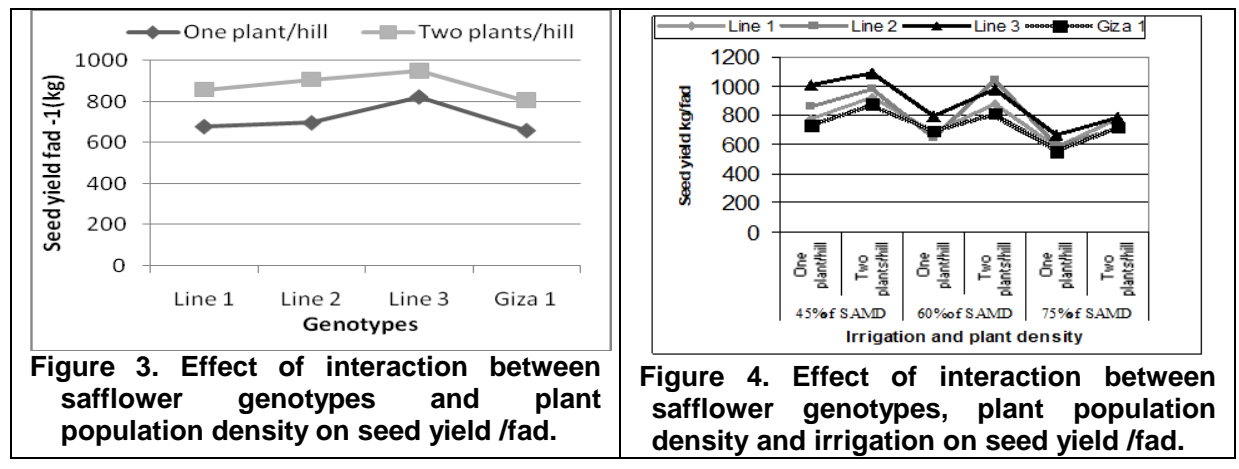

\section{Soil-water relations:}

\subsection{Water consumptive use (CU):}

Seasonal water consumptive use by safflower plants is presented in

Table 4, and showed that, seasonal water consumptive use values were 
$30.03,26.05$ and $23.95 \mathrm{~cm}$ when irrigated safflower plants at $45 \%, 60 \%$ and $75 \%$ of ASMD, respectively. These results indicated that water consumptive use increased, as soil moisture was maintained high by frequent irrigation.

Table 4: Monthly and seasonal water consumptive use $(\mathrm{cm})$ as affected by irrigation treatments, over both seasons.

\begin{tabular}{|l|c|c|c|c|c|c|c|}
\hline Irrigation & \multicolumn{4}{|c|}{ Monthly water consumptive use (cm) } & Seasonal \\
\cline { 2 - 7 } treatments & Nov. & Dec. & Jan. & Feb. & Mar. & April & C.U(cm) \\
\hline $45 \%$ of SAMD & 2.35 & 3.20 & 4.60 & 6.75 & 10.02 & 3.11 & 30.03 \\
$60 \%$ of SAMD & 2.35 & 2.75 & 3.55 & 6.05 & 9.08 & 2.24 & 26.05 \\
$75 \%$ of SAMD & 2.35 & 2.65 & 3.19 & 5.32 & 8.40 & 2.04 & 23.95 \\
\hline
\end{tabular}

This increase for seasonal water consumptive use at $45 \%$ of ASMD may be to higher water around root zone provides chance for more consumption of water that ultimately resulted in increasing transpiration by plants and evaporation from the soil surface. These results were in harmony with Katara and Bansal (1995) and Ibrahim et al (2008) who mentioned that water consumptive use by safflower plants increased as the available soil moisture around the root zone increased.

Monthly water consumptive use value started low at the beginning of safflower plant growing season, and increased gradually to reach its maximum value at March, as a result of the increase in vegetative growth that requires higher water consumption to plants, then it declined at maturity.

\subsection{Water use efficiency (WUE):}

Water use efficiency expressed in $\mathrm{kg}$ of seed yield $/ \mathrm{cm}$ of water consumed is presented in Table 3 . Results indicated that irrigation at $60 \%$ of ASMD gave the highest value of WUE $(31.32 \mathrm{~kg}$ seed yield $/ \mathrm{cm}$ of water consumed), while the lowest $(28.09 \mathrm{~kg} / \mathrm{cm})$ resulted from irrigation at $75 \%$ of ASMD. These findings could be attributed to the highly significant differences among seed yield due to irrigation treatments, as well as differences between water consumptive uses. These results are in line with those reported by Ibrahim et al (2008) who showed that the best water use efficiency (WUE) for seed production was obtained from irrigated safflower plants at $60 \%$ of ASMD.

Averaged over irrigation treatments, plant population density and seasons, Line 3 had WUE values that were 10.2, 14.7 and $20.4 \%$ greater than genotypes of Lines 2, 1 and Giza1 cv, respectively. This is logic because Line 3 gave the highest value of seed yield /fad. (Table 3 ). These results are confirmed with those obtained by Ibrahim et al (2008) who showed that Line 11 gave the best WUE.

Increasing plant population density from 35000 to 70000 plants /fad. significantly increased WUE as shown in Table 3. Plant densities at 70000 plants /fad. (two plans /hill) significantly enhanced WUE by $23.7 \%$ compared with plant densities at 35000 plants /fad. (one plan /hill). Also, this finding could be attributed to increased seed yield due to high plant densities.

Data in Table 3 showed that interaction effect between irrigation regime $\mathrm{x}$ genotype, irrigation regime $\mathrm{x}$ plant population density as well as plant population density $x$ genotype was significant for WUE. The highest 
values of WUE of 34.83 or $34.03 \mathrm{~kg}$ seed yield / $\mathrm{cm}$ of water consumed, were obtained when planted safflower Line 3 and irrigated at $45 \%$ or $60 \%$ of ASMD, respectively , while, the lowest value $(26.73 \mathrm{~kg} / \mathrm{cm})$ resulted from irrigation at $75 \%$ of ASMD with Giza $1 \mathrm{cv}$.(Figure 5). Also, the highest and the lowest values of WUE (35.62 and $24.96 \mathrm{~kg}$ seed yield $/ \mathrm{cm}$ of water consumed), were obtained from irrigation at 60 of ASMD at 70000 plants fad $^{-1}$ and $75 \%$ of ASMD at 35000 plants /fad, respectively (Figure 6). Different response of safflower genotypes to increasing plant population density concerning WUE is presented in Figure 7 . Increasing plant population density from 35000 to 70000 plants /fad increased WUE by 27.0, 30.8, 16.1 and $22.3 \%$ for Lines 1, 2, 3 and Giza1 cv, respectively. Same seed yield /fad., the second order interaction between three factors was significant for WUE. The data presented in Figure 8, indicated that Line 3 produced the highest value of WUE when planting at 70000 plants /fad. (two plants /hill) and irrigated at $60 \%$ of ASMD.

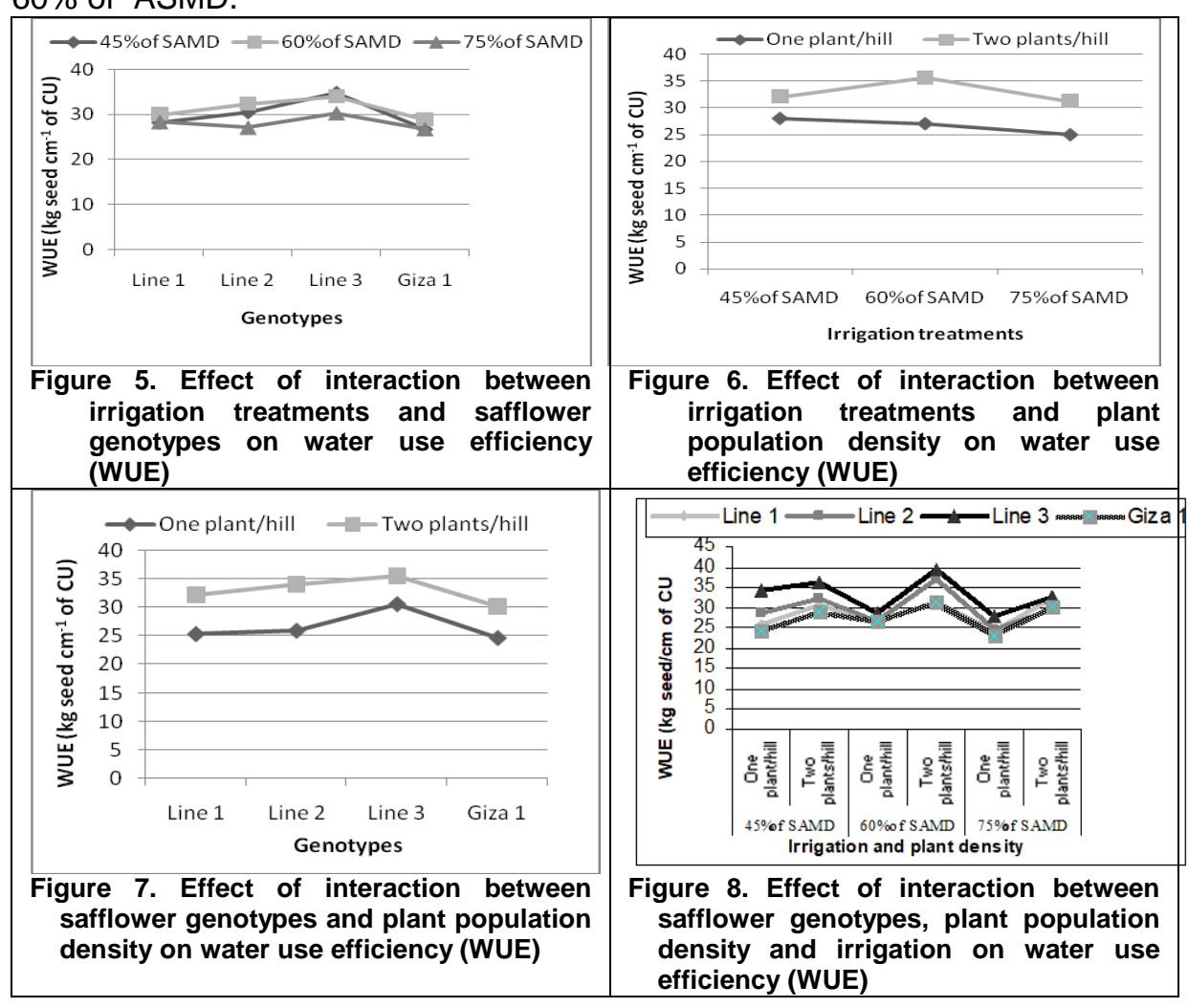

\section{REFERENCES}

A. O. A. C. 1984. Official Methods of Analysis of Association of Official Agricultural Chemists. Published by the Association of Official Analytical Chemists. Washington 25, D.C., U.S.A. 
Abo-Shetaia, A.M.A. 1990. Response of yield and yield components of safflower (Carthamus tinctorius L.) to increasing levels of nitrogen and phosphor under two levels of plant stand density. Annals Agric. Sci., Fac. Agric., Ain Shams Univ., 35 (1): 223-241.

Camas, N., C. Ctrak and E. Esendal. 2007. Seed yield, oil content and fatty acids composition of safflower (Carthamus tinctorius L.) grown in northern Turkey conditions. J. of Agric., OMU, Turkey, 22 (1): 98-104.

Cassel, D.K., and D.R. Nielsen. 1986. Field capacity and available water capacity. Methods of Soil Analysis. Part I. Physical and Mineralogical Methods. Agronomy Monograph No. 9, In: Klute, A. (ed.) Soil Sci. Soc. Am., Madison, Wisconsin, pp. 901-926.

Duncan, D.B. 1955. Design and Analysis of Experiments. $2^{\text {nd }}$ Ed., John Wiley and Sons. Inc., New York, U.S.A.

Eid, M.I. 1991. Physiological studies on growth, flowering and component of Carthamus tinctorius L. plant. Ph.D. Thesis, Fac. of Agric. Moshtohor, Zagazig Univ., Egypt.

El-Gayar, M.A., Abd El-Gawad and M.S. Barsoum. 1990. Differential behavior of some promising safflower mutant lines as affected by potassium fertilizer under calcareous soil conditions in Egypt. Proc. $4^{\text {th }}$ Conf. Agron., (11)13-28, Cairo, 15-16 Sept.

El-Hariri, D.M. and A.M. Ahmed. 1993. Response of safflower yield to plant density and nitrogen level. Annals of Agric. Sci., Moshtohor, 31 (2): 729-738.

Ghanem, S.A.I. and S.M.I. Ash-Shormillesy. 2007. Effect of plant distribution pattern and nitrogen fertilization on yield and photosynthates partitioning of safflower. Bull. Fac. Agric., Cairo Univ., 58 (1): 1-10.

Gomez, K.A. and A.A. Gomez. 1984. Statistical Procedures for Agricultural Research. John Willey and Sons. Inc, New York, U.S.A.

Gonzalez, J.L., A.A. Schneiter, N.R. Riveland and B.L. Johnson. 1994. Response of hybrid and open-pollinated safflower to plant population. Agron. J., 86 (6): 1070-1073.

Grossmann, R.B., Reinsch, T.G., 2002. Bulk density and linear extensibility, in: Methods of Soil Analysis. Part 4. Physical Methods. SSSA Book Series, No. 5, Soil Sci. Soc. Am., Madison, Wisconsin, pp. 201-228.

Hansen, V.W., D.W. Israelsen and Q.E. Stringharm. 1979. Irrigation principle and practices, $4^{\text {th }}$ ed. John Wielly \& Sons., New York.USA.

Ibrahim. A.F., A. N. Sharaan and A. W. El Wakil. 2008. Water requirements of safflower entries in middle Egypt. J. of Agron. and Crop Sci., 167 (3):170 - 175.

Jensen, M.E. 1983. Design and operation of farm irrigations systems. Amer. Soc. Agric. Eng. St. Joseph Michigan, USA.

Katara, G.S. and K.N. Bansal. 1995. Effect of irrigation and nitrogen on yield, uptake and water use efficiency of safflower (Carthamus tinctorius L.). Indian J. of Agron. 40 (2): 338-339.

Koutroubas, S.D., Papakosta, D.K., 2005. Adaptation, grain yield and oil content of safflower in Greece. VIth International Safflower Conference, Istanbul 6-10 June 2005 161-167. 
Mekki, B.B., M.S.A. Abo El-Kheir and S.A. Kandil. 1993. Effect of water stress on some safflower varieties. Ann. Agric. Sic., Moshtohor, 31 (2): 739 749.

Mundel, H.H. and J.P. Braun. 1999. Registration of two early-maturing safflower germplasm line with high oleic and high oil content. Crop Sci. (39): 298-299.

Mundel, H.H., H.C. Huang and J.P. Braun. 1999. Registration of lesaf 414, an early-maturing safflower germplasm line. Crop Sci. (39): 300-301.

Pourhadian, H. and M. R. Khajehpour. 2008. Effects of row spacing and planting density on growth indices and yield of safflower, local variety of Isfahan "Koseh" in summer planting. J. Sci. \& Technol. Agric. \& Natur. Resour., Vol. 11, No. 42 (A).

Rahamatalla, A.B., Babiker, E.E., Krishna, A.G., El Tinay, A.H., 2001.Changes in fatty acids composition during seed growth and physicochemical characteristics of oil extracted from four safflower cultivars. Plant Foods for Human Nutrition, 56: 385-395.

Weiss, E.A. 2000. Oilseed Crops (second edition). Blackwell Sci., Oxford.

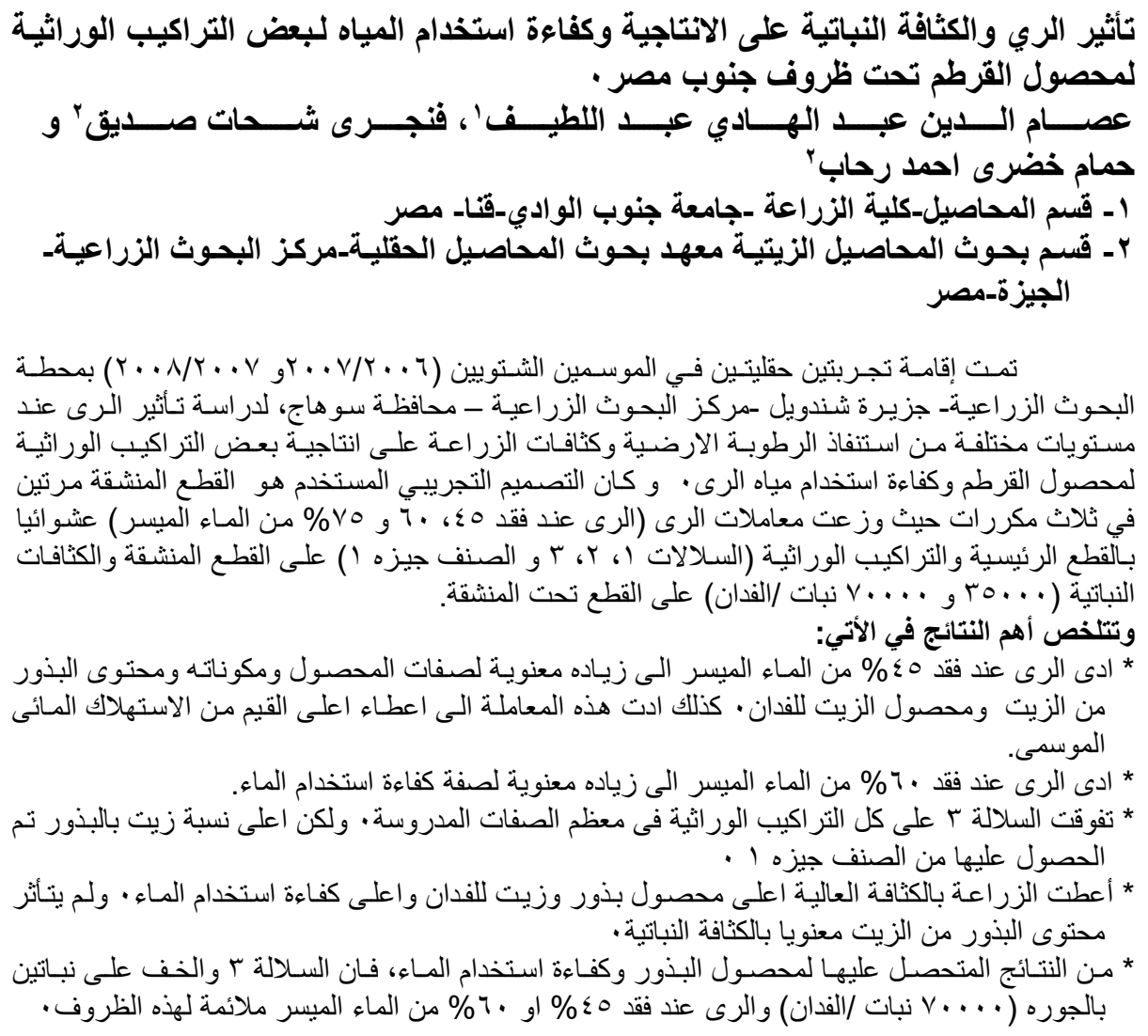

